\title{
Annals of Forest Research: 80 years from first publishing
}

\author{
S. Popescu, I.-A. Biriș, M. Teodosiu, O. Bouriaud, N. Olenici, D. Mohor
}

\begin{abstract}
Popescu S., Biriș I.-A., Teodosiu M., Bouriaud O., Olenici N., Mohor D., 2014. Annals of Forest Research: 80 years from first publishing. Ann. For. Res. 57(1): 3-4, 2014.

Authors. Sorin Popescu - Texas A\&M University, 221D Centeq Building, TAMU 2123, College Station, TX 77843, USA; Iovu-Adrian Biriş (iovu.biris@gmail. com), Dana Mohor - Forest Research and Management Institute, Eroilor Avenue 128, 077190 Voluntari, Ilfov, Romania; Marius Teodosiu, Olivier Bouriaud, Nicolai Olenici - Forest Research and Management Institute, Station Câmpulung Moldovenesc, 725100 Câmpulung Moldovenesc, Suceava, Romania.

Manuscript received May 19, 2014; revised May 23, 2014; accepted May 27, 2014; online first June 05, 2014.
\end{abstract}

80 years is worth a man's life time. Much happened since its first edition, different obstacles challenged its publication following its native contry's events, but the journal has succeeded in evolving and gaining audience. It now enters a new phase, having confirmed its status of leading East-European forestry and ecology journal.

The first edition published by Institutul de Cercetări şi Experimentație Forestieră (ICEF) - initial name of Forest Research and Management Institute, the publisher of Annals of Forest Research - was ICEF Annals. The first number was published in 1934, one year after the establishment of ICEF.

In its 80 years of existence the journal has been published regularly with annual and semestrial issues, except for two interruptions after World War II (1947-1950) and after the political changes that occurred in Romania in
1989 (1989-2000). From the first issue until the present resumption of publication, the aim of the journal has been the dissemination of research results of work conducted at the institute and to provide scientific information to decision makers, practitioners and the academic environment in Romania, to facilitate access to state-of-the art information and science concerning forests and forest management.

The recent resuming of publication took place in 2001, in a modified context of social, political and economic changes occuring in the entire Eastern Europe, marked by an intensified cooperation with foreign partners. Under these circumstances, the aim of the journal has been to open it to foreign authors and develop an international profile and recognition. Starting with 2008, the journal has been published exclusively in English under the present name (Annals of Forest Research and Manage- 
ment Institute), as homage to the first name.

At present, Annals of Forest Research is a peer-reviewed open access journal with semestrial issues (print \& online), in which we publish articles, research notes, reviews on topics concerning silviculture and related fields usually associated with environmental sciences. The journal is indexed in the most important data-bases for scientific literature of the domain amongst them ISI Web of Science and Scopus.

With the wish to make the journal more easily accesible to readers, authors and reviewers and also for marking this anniversary moment, the journal has been moved on a new personalized Web platform with a system of electronic document identifying (DOI) and archiving system respectively. The entire electronic archive of Annals of Forest Research is available on this new platform, that supports the existing one, with articles published between 1934 -2007 also available online.

During the recent years of publishing, the journal has made significant progress in multiple aspects, for instance the increase of manuscripts number and topics, the diversity of author's country of origin and the quality of articles. All these aspects are the result of team effort that conjugates the activity of the Editorial Office with that of the Editoarial Board

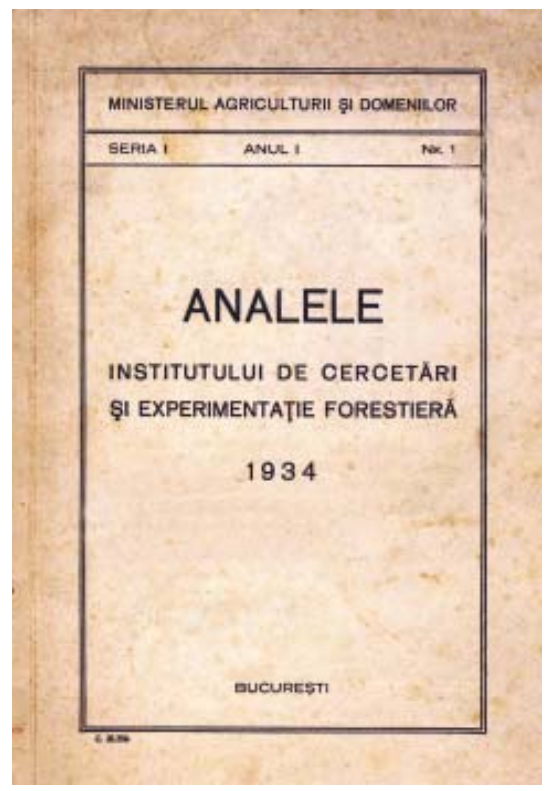

Cover of the first published volume

and peer-reviewers.

We are deeply trustful and confident in the future of the journal and consider that in spite of a very competitive and rapidly expanding environment of scientific publication, the Annals of Forest Research will continue to grow and consolidate its place and position.

We use this opportunity to thank everybody involved with the journal for their support, their professionalism, and contributions to the consolidation of journal's prestige. 